\title{
Biotechnology: identification and evaluation of the Bacillus cereus amylolytic activity
}

\author{
Biotecnologia: identificação e avaliação da atividade amilolítica de Bacillus cereus \\ Biotecnología: identificación y evaluación de la actividad amilolítica de Bacillus cereus
}

Received: 10/01/2021 | Reviewed: 10/09/2021 | Accept: 10/15/2021| Published: 10/18/2021

\author{
Jefferson Alves da Costa Júnior \\ ORCID: https://orcid.org/0000-0001-7572-3930 \\ Universidade Federal de Santa Maria, Brasil \\ E-mail: prof.jeffersoncostajunior@gmail.com \\ Genesio Mario da Rosa \\ ORCID: https://orcid.org/0000-0003-1247-2286 \\ Universidade Federal de Santa Maria, Brasil \\ E-mail: genesiomario@yahoo.com.br \\ Arci Dirceu Wastowski \\ ORCID: https://orcid.org/0000-0003-0255-5125 \\ Universidade Federal de Santa Maria, Brasil \\ E-mail: wastowski@ufsm.br \\ Hilda Hildebrand Soriani \\ ORCID: https://orcid.org/0000-0002-2563-7951 \\ Universidade Federal de Santa Maria, Brasil \\ E-mail: hildasoriani@gmail.com \\ Ana Paula Corteze Locatelli \\ ORCID: https://orcid.org/0000-0003-3341-1730 \\ Universidade Federal de Santa Maria, Brasil \\ E-mail: ana.p.locatelli@hotmail.com \\ Darlan Weber da Silva \\ ORCID: https://orcid.org/0000-0001-7681-5829 \\ Universidade Federal de Santa Maria, Brasil \\ E-mail: darlanweberdasilva@hotmail.com \\ Deisy Brasil Gonçalves \\ ORCID: https://orcid.org/0000-0002-4613-5563 \\ Universidade Federal de Santa Maria, Brasil \\ E-mail: deisy-b@hotmail.com \\ Gabriel Baraldi Volpi \\ ORCID: https://orcid.org/0000-0003-1757-6711 \\ Universidade Federal de Santa Maria, Brasil \\ E-mail: gabrielbvolpi_189@hotmail.com \\ Isabela Schamann Konzen \\ ORCID: https://orcid.org/0000-0001-9570-9917 \\ Universidade Federal de Santa Maria, Brasil \\ E-mail: isabelaskonzen@gmail.com \\ Kauane Andressa Flach \\ ORCID: https://orcid.org/0000-0001-8915-3289 \\ Universidade Federal de Santa Maria, Brasil \\ E-mail: kaauane_flaach@hotmail.com \\ Ubiratan Alegransi Bones \\ ORCID: https://orcid.org/0000-0002-2220-5686 \\ Universidade Federal de Santa Maria, Brasil \\ E-mail: ubiratan.bones@acad.ufsm.br
}

\begin{abstract}
Biotechnology is the branch of science that uses molecules, viruses, microorganisms, cells, animals, plants or part of them in technological processes to generate benefits for humans, to flora, fauna and the environment. In this context, enzymes are natural biocatalysts that present substrate specificity and extreme importance to vital processes, as they develop indispensable functions in biochemical reactions of cell metabolism, and can be used in biotechnological processes. Knowing the human needs, for a world population of about 7.7 billion people and the functional usefulness of enzymes, there is, on the one hand, a gigantic demand for the consumption of various products in the agricultural sector, processed and industrialized, such as: food, beverages, clothing in the textile sector, medicines, vaccines, cosmetics in the chemical-pharmaceutical sector, as well as in the production of paper and fuels, in which enzymes, mainly amylases, have been widely used in production processes. In this work, experiments were carried out with the wild Bacillus cereus bacterium to verify the production of amylases, the results obtained could demonstrate the formation of amylolysis halos around the colonies in Petri dishes containing Tryptic Soy Agar + starch (1\%) medium,
\end{abstract}


$\mathrm{pH} 7.3$ and grown in a biological oven at $37^{\circ} \mathrm{C}$ for 24 hours, when revealed in iodine vapor; the Amylolysis Index (AI) was 3.3 and the efficiency of starch substrate degradation by amylases was greater than $90 \%$ in the evaluated treatments.

Keywords: Amylase; Bacillus; Bioprocess; Biotechnology; Enzymes.

\begin{abstract}
Resumo
A biotecnologia é o ramo da ciência que utiliza moléculas, vírus, microrganismos, células, animais, plantas ou parte deles em processos tecnológicos para gerar benefícios para o homem, à flora, à fauna e ao meio ambiente. Nesse contexto, as enzimas são biocatalisadores naturais que apresentam especificidade aos substratos e extrema importância aos processos vitais, pois desenvolvem funções indispensáveis nas reações bioquímicas do metabolismo celular, podendo ser utilizadas em processos biotecnológicos. Conhecendo as necessidades humanas, para uma população mundial de cerca de 7,7 bilhões de pessoas e a utilidade funcional das enzimas, existe, por um lado, uma gigantesca demanda pelo consumo de diversos produtos do setor agrícola, processados e industrializados, tais como: alimentos, bebidas, vestuário no setor têxtil, medicamentos, vacinas, cosméticos no setor químico-farmacêutico, bem como na produção de papéis e combustíveis, nos quais as enzimas, principalmente amilases, têm sido amplamente utilizadas nos processos produtivos. Neste trabalho foram realizados experimentos com a bactéria Bacillus cereus de origem selvagem para verificar a produção de amilases; os resultados obtidos puderam demonstrar a formação de halos de amilólise ao redor das colônias em placas de Petri, contendo o meio Ágar Tríptona de Soja + amido (1\%), $\mathrm{pH}$ 7,3 quando cultivadas em estufa biológica a $37^{\circ} \mathrm{C}$ por 24 horas, quando reveladas em vapor de iodo; o Índice de Amilólise (IA) foi de 3,3 e a eficiência de degradação do substrato amiláceo, pelas amilases, foi superior a $90 \%$ nos tratamentos avaliados.
\end{abstract}

Palavras-chave: Amilase; Bacilo; Bioprocesso; Biotecnologia; Enzimas.

\title{
Resumen
}

La biotecnología es la rama de la ciencia que utiliza moléculas, virus, microorganismos, células, animales, plantas o parte de ellos en procesos tecnológicos para generar beneficios para los seres humanos, la flora, la fauna y el medio ambiente. En este contexto, las enzimas son biocatalizadores naturales que presentan especificidad a sustratos y son de suma importancia para procesos vitales, ya que desarrollan funciones esenciales en las reacciones bioquímicas del metabolismo celular, pudiendo ser utilizadas en procesos biotecnológicos. Conociendo las necesidades humanas, para una población mundial de alrededor de 7.700 millones de personas y la utilidad funcional de las enzimas, existe, por un lado, una demanda gigantesca para el consumo de diversos productos del sector agrícola, procesados e industrializados, tales como: alimentos, bebidas, confección en el sector textil, medicamentos, vacunas, cosméticos en el sector químico-farmacéutico, así como en la producción de papel y combustibles, en los que las enzimas, principalmente las amilasas, han sido ampliamente utilizadas en los procesos productivos. En este trabajo se realizaron experimentos con la bacteria Bacillus cereus silvestre para verificar la producción de amilasas; los resultados obtenidos permitieron demostrar la formación de halos de amilólisis alrededor de las colonias en placas Petri conteniendo medio Triptona Soy Agar + almidón (1\%), pH 7.3 y cultivadas en horno biológico a $37^{\circ} \mathrm{C}$ durante 24 horas, cuando se desarrolló en vapor de yodo; el Índice de Amilolisis (IA) fue de 3.3 y la eficiencia de degradación del sustrato almidonado, por amilasas, fue superior al $90 \%$ en los tratamientos evaluados.

Palabras clave: Amilasa; Bacilo; Bioproceso; Biotecnología; Enzimas.

\section{Introduction}

Biotechnology has been a fundamental tool in the search for solutions and optimization of bioprocesses related to issues of human, plant, animal, energy and also the balance of ecosystems on our planet. According to Brazil, 2010, biotechnology can be defined as "any technological application that uses biological systems, living organisms or their derivatives, to create or modify products and processes for specific uses". In the incessant search for solutions, biotechnology emerges as a tool with multiple functions and possibilities in the improvement and generation of new products, as well as the establishment of new markets, since it can make use of cellular systems for the development and improvement of processes and products of economic and social interest. Abreu et al., (2015), emphasizes the importance of biotechnology as an instrument in obtaining and producing several metabolic substances useful to human beings and to the environmental balance that come from the manipulation of fungi. Beattie et al., (2011), highlighted the importance of biotechnology through microbial prospecting that corresponds to the methods and tests used in the discovery of new bioactive compounds, from biological sources such as fungi and bacteria, capable of secreting substances of interest in the most diverse areas of human activity and need, such as such as: agriculture, pharmaceuticals, aquaculture, bioremediation, bioenergy and nanotechnology. In the 
bioprospecting of microorganisms, enzymes have shown high biotechnological interest, and the environmental compartment of the soil has been the ideal environment for the collection and isolation of microorganisms, mainly due to the great bacterial biodiversity present in nature (Singh, et al., 2011). With regard to enzymes, these are natural substances of protein origin associated with organic and inorganic cofactors, vitamins and mineral salts, respectively, involved in all cellular biochemical processes of synthesis and catalysis, sometimes composing simple molecules into complex ones and sometimes decomposing complex molecules into smaller units (monomers), such as in polysaccharide (starch) synthesis reactions from glucose and its decomposition into simple carbohydrates (triose) until its complete oxidation into $\mathrm{CO}_{2}$ and $\mathrm{H}_{2} \mathrm{O}$ with the release of energy (Oliveira, et al., 2004).

The use of enzymes as biocatalysts in industrial processes has been highlighted when compared to chemical catalysts, due to factors such as: biochemical safety, non-toxicity, energy reduction in the system, production time reduction, energy cost reduction in the production of products, economic viability and the fact that enzymes do not pollute the environment (Wohlgemuth, 2010). For Gopinath et al., (2017), enzymes of microbial origin have been the most used in industries due to: ease of handling, capacity for production in large volumes, ability to release to the extracellular environment, at low cost of production, reduced reaction time, stability in extreme conditions and possibility of expression and production of recombinant enzymes in host cells.

According to data from the Ministry of Industry, Foreign Trade and Services of the Brazil (2018), the country is essentially an importer of enzymes which are used in research and in the national industry. In the 2016/2017 period, Brazil spent US\$164.41 million on enzyme imports and only US\$58.93 million on exports. According to Pandey et al. (2000), although Brazil has a high potential for the production of enzymes, as it contains a vast microbial biodiversity in its national territory and has large amounts of low-cost substrates for bioprocesses - such as agricultural residues - the country does not yet it is self-sufficient in the production of enzymes, that is, $73.61 \%$ of the enzymes used are imported and only $26.39 \%$ are of national origin.

Among the main enzymes used in bioprocesses, amylases stand out for their ability to hydrolyze starch, a polysaccharide composed of amylose and amylopectin polymers. Amylose is a linear polymer, which contains more than 6,000 glucose monomers joined by $\alpha-1,4$-glycosidic bonds, while amylopectin consists of linear chains of 10-60 glucose units, joined by $\alpha-1,4-$ bonds. glycosidic and branched chains of 15-20 glucose units, joined by $\alpha-1,6$ bonds (Souza \& Magalhães, 2010). According to Pandey et al., (2006), amylases can be divided into four groups: the first is endohydrolases, such as $\alpha$-amylase (EC3.2.1.1./International Biochemistry Union) 1,4- $\alpha$ - D-Glucan-glucan hydrolase which is responsible for the hydrolysis of $\alpha$ 1,4-glycosidic bonds in the internal region of starch, generating glucose and maltose as reaction products. The second group are the exohydrolases that act on the non-reducing ends of the polysaccharide chain, which can be: $\beta$-amylase that hydrolyzes the $\alpha$-1,4-glycosidic bonds generating maltose dimers; $\alpha$-glucosidase that hydrolyzes $\alpha$-1,4-glycosidic bonds generating glucose units; amyloglucosidase (glucoamylase) that hydrolyzes $\alpha-1,4$ and $\alpha-1,6$ glycosidic bonds generating glucose units. The third group of amylases is composed of "debranching”, enzymes responsible for lysing the branches of the polysaccharide, such as isoamylases and pullulanases that hydrolyze $\alpha-1,6$ glycosidic bonds. The fourth group corresponds to transferases that cleave $\alpha-1,4$ glycosidic bonds transferring part of the molecules to an acceptor and forming a new glycosidic bond, such as cyclodextrins (Sundarram \& Murthy, 2014).

Amylase enzymes can have various origins, that is, naturally produced by plants, animals or microorganisms, the latter, highlighting the microbial enzymes that have greater demand in the world market, mainly due to factors such as: easy handling in the laboratory, rapid growth of organisms, high production on a large scale and greater stability (Gupta et al., 2003). The level of production of microbial amylases varies greatly from one organism to another, depending on the origin of the microorganism, the genus, species and lineage; strains isolated from naturally starchy environments produce the highest 
amounts of enzymes. In addition, factors such as $\mathrm{pH}$, temperature, carbon and nitrogen sources are added, which influence the production of amylase in fermentation processes (Gopinath et al., 2017).

In the Monera kingdom, several bacterial species capable of producing amylases for industrial use are found, which have been obtained mainly from Bacillus genus bacteria, such as: Bacillus subtilis, B. licheniformis, B. stearothermophilus and B. amyloliquefaciens, since they are capable of producing thermostable amylases (Souza \& Magalhães, 2010). Depending on their origin, amylases are also capable of reacting in different concentrations of salts, such as those from halophilic bacterial strains isolated from oceans, such as Marinobacter sp. (Kumar \& Khare, 2015) and Rhodothermus marinus (Yoon et al., 2008).

There are several industrial sectors that use amylases at some stage of manufacture, such as in the production of glucose and fructose from starch conversion, for example: in the manufacture of corn glucose syrup. According to Van Der Maarel et al., 2002, amylases have been used in the paper, detergents (to enhance stain removal), starch (polysaccharide molecular weight reduction, to obtain viscosity and sweetness) industries. including being able to act in the hydrolysis process together with cellulases, proteases and lipases (enzymatic cocktail), in addition to being an organic compound that does not pollute the environment (Hmidet et al., 2009). Amylases can also be used for the production of biofuel, such as ethanol, from the enzymatic hydrolysis process of the starch substrate, which is easily found in nature or with industrial residues, achieving a low production cost (Chi et al., 2009). In the processed food industry, amylases can also be used during the baking steps, such as in the production of cakes, fruit juices and starch syrup (Couto \& Sanromán, 2006), as well as in the textile industry for starch removal (Dalvi et al., 2007); it is noteworthy that part of these industrialized products have been destined for export trade (Brazil, 2018).

As already highlighted, amylases are among the most important industrial enzymes, with great biotechnological importance. Despite coming from different sources, including plants, animals and microorganisms, microbial enzymes generally meet the industrial demand satisfactorily. Currently, large amounts of microbial amylases are commercially available and have applications in the food, beverage and cleaning products sector, accounting for $14 \%$ of the total demand for industrial enzymes (Gupta et al., 2003; Pandey et al., 2006). According to Politzer et al., 2006, the food and beverage sectors accounted for more than 50\% of the world demand for amylases. Amylases constitute one of the most important groups of enzymes with applications in different industries such as food, textile, chemical, pharmaceutical and detergents (Nielsen \& Borchert, 2000; Gupta et al., 2003; Surmely, 2003; Demirkan et al., 2005; Soccol, 2006; Pandey et al., 2006).

Among the amylolytic enzymes, $\alpha$-amylase is the most important, as it plays a fundamental role in the conversion of starch into low molecular weight glycosidic products, which can be used by other enzymes of the same group. In industrial processes, it is intended that $\alpha$-amylases are thermophilic, that is, have hydrolytic activity at high temperatures, as in the gelatinization step: 70 to $90^{\circ} \mathrm{C}$ and liquefaction: 100 to $110^{\circ} \mathrm{C}$ of starch (Sidhu et al., 1997; Sarikaya et al., 2000; Peixoto et al., 2003). Among the thermophilic $\alpha$-amylases, industrially, those produced by thermophilic microorganisms, such as Bacillus genus bacteria, stand out due to the following characteristics: stability at high temperature and $\mathrm{pH}$.

Among the 48 Bacillus species already described, 32 produce $\alpha$-amylase, but only a few of these are capable of secreting active enzymes at high temperatures. In the genus Bacillus, the species: B. amyloliquefaciens, B. stearothermophilus, B. subtilis and B. licheniformis are the four most used species in the industrial production of $\alpha$-amylases (Sajedi et al., 2005; Souza \& Magalhães, 2010). Among the main advantages of using thermostable $\alpha$-amylases in industrial processes, there is a reduction in the risk of contamination, an increase in the rate of diffusion of reagents and a reduction in costs with external refrigeration (Lin et al., 1998).

According to Pandey, 2003, the bacterium Bacillus cereus is considered one of the main microorganisms capable of producing amylase enzymes, in addition to B. megaterium, Bacillus subtilis, B. licheniformis, B. amyloliquefaciens, as well as 
the fungi Aspergillus niger, Penicillium sp, Cephalosporium sp, Rhizopus sp and Neurospora sp. The $\alpha$-amylase produced by Bacillus genus has an apparent molecular weight of $50 \mathrm{kDa}$, is stable in a pH range from 5.5 to 9.0 and remains active even at elevated temperatures between 80 and $90^{\circ} \mathrm{C}$. Its biosynthesis is controlled by both substrate induction and catabolic repression, being produced at the end of the exponential growth phase and at the beginning of the stationary phase. It presents itself as an extracellular enzyme, but small amounts of the enzyme can remain attached to the membrane (Morcel \& Biedermann, 1994). Bacillus $s p$ is a gram-positive, rod-shaped bacterium, mobile by peritric and sporogenic flagella (Welker and Campbell, 1967). The species was originally isolated from soils and obtained this classification for its ability to secrete large amounts of amylases. Bacillus amyloliquefaciens is also capable of producing a variety of other enzymes, such as: galactanase, isoamylase, mannanase, xylanase, metal-protease, serine-protease, alkaline phosphatase and ribonuclease (Priest, 1977). The range of enzymes produced by Bacillus species corresponds to about $50 \%$ of commercially produced bacterial enzymes. The wide use of Bacillus in industry is due to the ease of growth of these species, such as the temperature range that varies from 30 to $40^{\circ} \mathrm{C}$ and $\mathrm{pH} 6.0$ - 7.0 for optimal growth; also for presenting, naturally, high levels of extracellular enzymes and for being considered a non-pathogenic species (Shimada et al., 1985; Vehmaanperä et al., 1991). The production of $\alpha$-amylase of microbiological origin can occur in various forms of processes, such as in solid or submerged fermentations, taking into account the conditions of the bioprocess, such as the type of fermentation, the concentration of nutrients, the speed of agitation/aeration, $\mathrm{pH}$ and temperature, which can be modified in order to optimize microbial growth and enzyme production (Milner et al., 1996). In the production of amylases by Bacillus, the aeration rate must be taken care of, as the amount of oxygen dissolved in the medium is an important factor in the fermentation process. On a laboratory scale, the aeration rate needed to maintain the proper level of dissolved oxygen is on the order of one volume of air per volume of fermentation medium per minute; other studies have shown that the system's aeration can be interrupted in the stationary phase, controlling the $\mathrm{pH}$, without significant losses in enzyme yield (Milner et al., 1996). Regarding the carbon source, the production of $\alpha$ amylase by bacteria of the genus Bacillus is usually induced by the presence of the starch substrate or its hydrolytic product, maltose. Several studies demonstrate that starch and maltose act as inducers of $\alpha$-amylase activity. On the other hand, the presence of sugars, such as xylose and fructose, act as repressors of enzyme synthesis, reducing its production (Gupta et al., 2003). The availability of nitrogen is essential in the culture medium for the microbial growth of Bacillus species and, consequently, for the production of enzymes. In synthetic culture media, the addition of organic nitrogen, such as meat extract and peptone, has been preferred for bacterial amylases production. However, several sources of inorganic nitrogen have been reported for better production of amylase by fungi, such as ammonium sulfate, ammonium nitrate (Gupta et al., 2003); $\mathrm{pH}$ is another factor with a strong influence on the production of amylases. Most Bacillus strains used commercially in the production of bacterial $\alpha$-amylases, by submerged fermentation, show excellent growth in the $\mathrm{pH}$ range between 6 and 7 , which may vary according to the genus and species of the producing bacteria (Gupta et al., 2003). Temperature is also one of the most important factors in the production of enzymes, as it acts in the environmental system of microorganism growth in a decisive way in the functions of biomolecules, in the stability and maintenance of biological structures. Thus, bacterial amylases from Bacillus cereus, B. amyloliquefaciens, B. subtilis, B. licheniformis and B. stearothermophilus are industrially produced at temperatures ranging from $37^{\circ}$ to $60^{\circ}$ degrees Celsius (Swetha et al., 2006).

Another biotechnological potential explored in microorganisms is as probiotics, as they present health benefits when ingested, such as: balance of the intestinal microbiota, chemiosmotic balance in the intestinal system, reduction of diarrhea, control of cholesterol and triglycerides, anti-inflammatory effect, antimicrobial activity, anti-tumor activity, immune system modulator, cancer reduction. Added to this are the characteristics of rapid cell reproduction, ability to produce antimicrobial substances, ability to resist the digestive process of animals, production of enzymes (phytase, cellulase, amylases, Bgalactosidase) and non-pathogenicity, such as those of the genera Lactobacillus, Bifidobacterium, Enterococcus, 
Saccharomyces, Bacillus cereus, Bacillus subtilis, B. licheniformis, B. pumilus, B. clausii, B. coagulans, B. thuringiensis (Ibrahim, 2000; Fao/Who, 2001; Mattila-sandholm et al, 2002; Hong et al, 2005; Malkov et al, 2005; Begley et al, 2006; Parvez et al, 2006; Rhodes, 2006; Vasiljevic \& Shah, 2008; Nedelcheva et al, 2010; Abriouel et al, 2011; Nithya \& Halami, 2013). Bacillus cereus has been used as an antimicrobial in the treatment of gastrointestinal diseases, diarrhea caused by bacteria and rotavirus, under the trade names Subtyl, Bactisubtil, Paciflor, Toyocerin (Ishibashi et al, 2001, Hong et al, 2005).

\section{Material and Methods}

The experiments were developed based on the works of Caraway (1959), Hankin and Anagnostakis (1975), Astolfi Filho et al. (1986), Rajkowski and Bennett (2003); Carrín et al. (2004), Morita and Assumpção (2007), Ashwini et al. (2011).

\subsection{Biological Material}

The experiments were carried out at the Microbiology Laboratory, block 7 of the Federal University of Santa Maria, Frederico Westphalen Campus (UFSM - FW). The microorganism was isolated from the rhizome of the plant Edychium choronarium, collected in the forest of the Municipality of Frederico Westphalen-RS (Brazil), being inoculated in Muller Hinton Broth medium and selected in Petri dishes containing Muller Hinton Agar medium, both were grown under standard conditions of temperature $\left(37^{\circ} \mathrm{C}\right), \mathrm{pH}=7.0$ and incubation time of 24 hours; initially in a Shaker type incubator (Luca 220 Lucadema, regulated at $140 \mathrm{rpm}$ ), and later in a B.O.D. SL 200.

\subsubsection{Identification of Biological Material}

a) Morphological. The microorganism was identified by visualizing its morphological structure with the aid of the OPTON TIM - 30 Binocular Stereomicroscope equipment, in a Petri dish, Muller Hinton Agar medium. Bacterioscopy was used to identify the shape and arrangement of the bacteria, through microscopic observation in the Digilab Planachromatic Trinocular Biological Microscope (10x Eyepiece; Achromatic Objectives: 4x, 10x, 40x, 100x(R) oil).

b) Molecular: Taxonomy Classification. Target DNA amplification (PCR). The Consensus sequences were generated by BioEdit (HALL, 1999) from sequences obtained in Polymerase Chain Reactions by primers) 27F (5' AGAGTTTGATCMTGGCTCAG-3') and 1492R (5'- TACGGYTACCTTGTTACGACTT - 3'), according (WEISBURG et al., 1991). The taxonomic classification of the samples was based on the comparison between the consensus sequence and those deposited in GenBank (www.ncbi.nlm.nih.gov/)-MEGABLAST. The unique sequence was aligned with similar ones available in the database and a phylogenetic distance tree was built using the MEGA 7 program (Kumar et al., 2016). Analyzes were carried out in the laboratories of the Tropical Culture Collection of the André Tosello Foundation (CCT - FAT)/ São Paulo-Brazil.

\subsection{Gram Stain}

The GRAM staining technique (Brasília, 2001) was used to characterize the microorganism, the same being observed in a Digilab Planachromatic Trinocular Biological Microscope.

\subsection{Growth of Microorganism in Liquid Medium}

The microorganism, obtained from the isolation plates (Muller Hinton Agar), was inoculated in Tryptic Soy Broth medium with $\mathrm{pH} 7.3$ in $250 \mathrm{~mL}$ Erlenmayer. The inoculum was grown for 24 hours in a Shaker Luca 220 - Lucadema Incubator, regulated at $140 \mathrm{rpm}$, with a constant temperature of $37^{\circ} \mathrm{C}$. 


\subsubsection{Growth in Solid Medium with Starch}

The microorganism was inoculated in Petri dishes containing Tryptic Soy Agar growth medium added with starch (1\%) for 24 hours in a B.O.D. SL 200 at $37^{\circ} \mathrm{C}$.

\subsubsection{Qualitative Analysis of Starch Substrate Consumption}

Inoculums of the microorganism were grown in Petri dishes containing Tryptic Soy Agar medium added with starch (1\%) for 24 hours in a B.O.D. SL 200 at temperature of $37^{\circ} \mathrm{C}$ and, subsequently, submitted to iodine vapors to verify the formation of amylolysis halos around the colonies, in order to characterize the amylolytic activity of the bacteria - (Hankin and Anagnostakis, 1975; Astolfi Filho et al., 1986; Ashwini et al., 2011).

\subsection{Construction of the Starch Standard Curve}

The standard curve (calibration) of starch was constructed using the spectrophotometry technique by the reaction of starch with Iodine/Lugol (Morita and Assumpção, 2007), modified from Carrín et al., 2004. The aliquots, containing different concentrations of the solution of starch, were added with Lugol's solution and transferred ( $2 \mathrm{~mL}$ of mixture volume) in glass cuvettes (Glass) to carry out the Transmittance and Absorbance readings $(\lambda 620 \mathrm{~nm})$ in the spectrophotometer (Nanocolor Visivel - Macherey Nagel).

\subsection{Microorganism Growth in Inducer Medium for Amylolytic Enzyme Production}

Inoculums of the amylolytic microorganism were grown in Tryptic Soy Broth liquid medium added with a starch solution (2\%) to induce the production of amylase enzymes. The medium was sterilized in an autoclave Digitale AV 30, at $121^{\circ} \mathrm{C}$ for 15 minutes. The final growth medium had $\mathrm{pH} 7.3$ measured in a pHmeter-Akso device. The inoculation of the microorganism in Tryptic Soy Broth + starch medium took place in a Lutech laminar flow chamber. The growth of the microorganism took place in an Incubator Shaker Luca 220 - Lucadema, regulated at $140 \mathrm{rpm}$, at a temperature of $37^{\circ} \mathrm{C}$ for 24 hours.

\subsection{Obtaining Enzymes - Transfer of Inoculum, Centrifugation and Separation of Supernatant from Cells}

After 24 hours of growth of the microorganism in Tryptic Soy Broth + starch medium under standardized conditions, the liquid medium was divided into $10 \mathrm{~mL}$ volumes and placed in 10 sterile Falcon tubes. These were followed by centrifugation in a Daiki Spinplus centrifugal device under conditions of 5,000 rpm for 15 minutes. From the centrifuged material, the supernatant was carefully removed and transferred to sterile and closed test tubes. Of the supernatant material (enzymatic solution), half was stored in a refrigerated environment of $4^{\circ} \mathrm{C}$, and the other half was filtered in a $0.22 \mu \mathrm{m}$ millipore membrane, being subsequently kept under the same refrigeration conditions.

\subsection{Enzyme Activity Analysis (AE)}

\subsubsection{Avaliação do Índice de Amilolise (IA)}

The amylolysis index (AI) is a potential estimate of the amylolytic activity of microorganisms on the starch substrate, obtained by visual assessment and calculated by the ratio between the "diameter of the amylolysis halo and the diameter of the colony". AI values above 2.0 denote excellent production capacity and enzyme action. Amylolysis halos are well visualized after the development of the growth plate on iodine vapor (Astolfi Filho et al., 1986). 


\subsubsection{Construction of the Enzyme Activity curve, as defined in the treatments described below:}

- T1 (100 $\mu$ L Enzyme Solution - centrifuged supernatant solution);

- T2 (10 $\mu$ L Enzyme Solution - centrifuged supernatant solution);

- T3 (10 $\mu \mathrm{L}$ Enzyme Solution - centrifuged and membrane-filtered supernatant solution of $0.22 \mu \mathrm{m}$ - Millipore)

- T4 (100 $\mu \mathrm{L}$ Enzyme Solution - centrifuged and membrane-filtered supernatant solution of $0.22 \mu \mathrm{m}$ - Millipore)

*Equipment used for recording absorbance/transmittance: Nanocolor Visible Device - Macherey Nagel, $\lambda=620 \mathrm{~nm}$. Standard Reaction Solution: distilled water, lugol, starch solution (1\%w/v) + Enzyme (Treatments).

\subsubsection{Amylase Activity Analysis}

This analysis was performed by the colorimetric method adapted from Caraway, 1959. The stock enzyme solutions were obtained from the supernatant of Bacillus sp. cultures, by centrifugation at 5,000 rpm/15 min, which were placed in sterilized test tubes with lids and stored under refrigeration at $4^{\circ} \mathrm{C}$. The analysis of amylase activity was performed by the starch hydrolysis reaction over time and measured in a spectrophotometric device by reading the Absorbance/Transmittance at a wavelength of $620 \mu \mathrm{m}$ for the construction of the Enzymatic Activity Curve (AE).

\section{Results}

\subsection{Microorganism Identification e Classification}

A) Morphological. The observation of the microorganism colonies by direct microscopy in a Petri dish, after the period of growth in Muller Hinton Agar medium, allowed the verification of smooth cream-colored colonies in the central region and a light rough appearance in the peripheral region (Figure 1).

Figure 1 - Visualization of structures of Bacillus cereus colonies in solid culture media (Muller Hinton Agar).

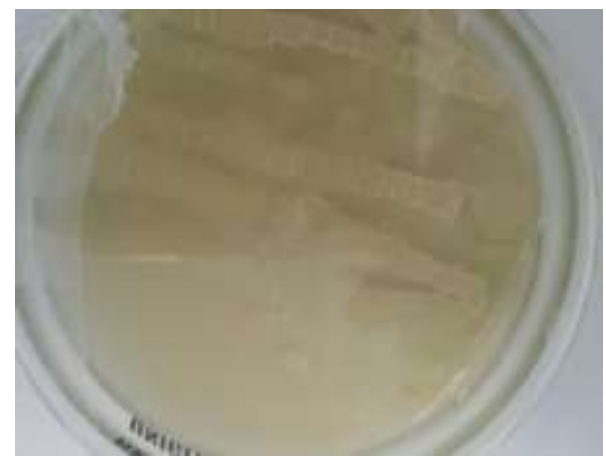

Source: Authors (2021).

By optical microscopy (1,000x magnification) and the GRAM staining technique, it was confirmed that the bacteria was positive (Gram+). Microscopic observation resulted in the identification of bacteria in the form of bacillus and in a chain arrangement (streptobacillus); measuring $1.0-1.2 \mu \mathrm{m}$ width and 3.0 a $5.0 \mu \mathrm{m}$ length and forming ellipsoidal spores (Rajkowski \& Bennett, 2003; Logan and de Vos, 2009), pictured in figure 2 (a and b). With the results obtained and the support of bibliographical references (Bergey's Manual of Systematic Bacteriology), it was concluded that it was the bacterium of the species Bacillus cereus. 
Figure 2 - Bacteria, bacillus type (a,b) observed under a microscope (1,000x), image captured with projection on a notebook screen.

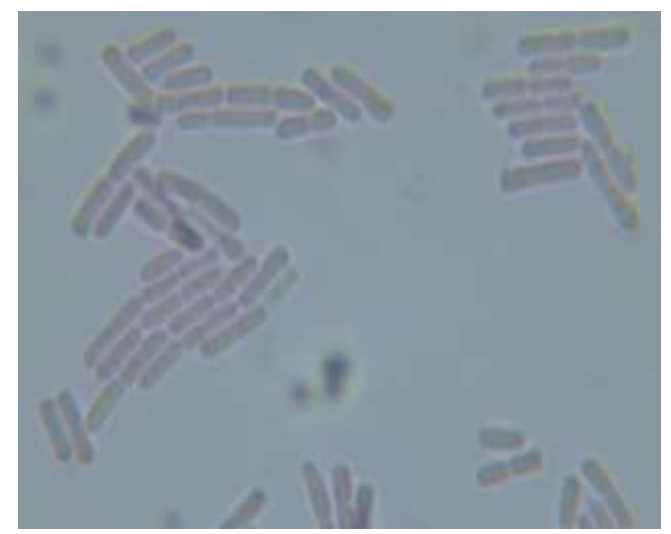

a) $\operatorname{Gram}(+)$

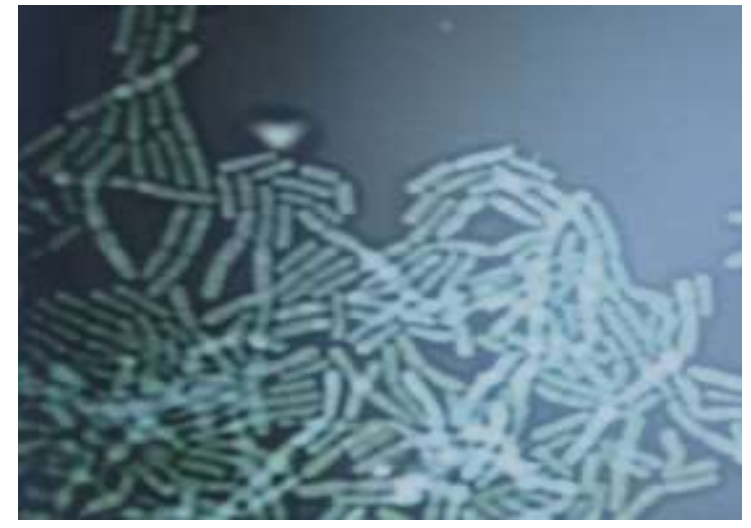

b) Streptobacillus arrangement

Source: Authors (2021).

B) Molecular: Taxonomy Classification.

Sequência:>591-1

CAAGTCGAGCGAATGGATTAAGAGCTTGCTCTTATGAAGTTAGCGGCGGACGGGTGAGTAACACGTGG GTAACCTGCCCATAAGACTGGGATAACTCCGGGAAACCGGGGCTAATACCGGATAACATTTTGAACNGCATGGT TCGAAATTGAAAGGCGGCTTCGGCTGTCACTTATGGATGGACCCGCGTCGCATTAGCTAGTTGGTGAGGTAACG GCTCACCAAGGCAACGATGCGTAGCCGACCTGAGAGGGTGATCGGCCACACTGGGACTGAGACACGGCCCAGA CTCCTACGGGAGGCAGCAGTAGGGAATCTTCCGCAATGGACGAAAGTCTGACGGAGCAACGCCGCGTGAGTGA TGAAGGCTTTCGGGTCGTAAAACTCTGTTGTTAGGGAAGAACAAGTGCTAGTTGAATAAGCTGGCACCTTGACG GTACCTAACCAGAAAGCCACGGCTAACTACGTGCCAGCAGCCGCGGTAATACGTAGGTGGCAAGCGTTATCCGG AATTATTGGGCGTAAAGCGCGCGCAGGTGGTTTCTTAAGTCTGATGTGAAAGCCCACGGCTCAACCGTGGAGGG TCATTGGAAACTGGGAGACTTGAGTGCAGAAGAGGAAAGTGGAATTCCATGTGTAGCGGTGAAATGCGTAGAG ATATGGAGGAACACCAGTGGCGAAGGCGACTTTCTGGTCTGTAACTGACACTGAGGCGCGAAAGCGTGGGGAG CAAACAGGATTAGATACCCTGGTAGTCCACGCCGTAAACGATGAGTGCTAAGTGTTAGAGGGTTTCCGCCCTTT AGTGCTGAAGTTAACGCATTAAGCACTCCGCCTGGGGAGTACGGCCGCAAGGCTGAAACTCAAAGGAATTGAC GGGGGCCCGCACAAGCGGTGGAGCATGTGGTTTAATTCGAAGCAACGCGAAGAACCTTACCAGGTCTTGACAT CCTCTGAAAACCCTAGAGATAGGGCTTCTCCTTCGGGAGCAGAGTGACAGGTGGTGCATGGTTGTCGTCAGCTC GTGTCGTGAGATGTTGGGTTAAGTCCCGCAACGAGCGCAACCCTTGATCTTAGTTGCCATCATTAAGTTGGGCAC TCTAAGGTGACTGCCGGTGACAAACCGGAGGAAGGTGGGGATGACGTCAAATCATCATGCCCCTTATGACCTGG GCTACACACGTGCTACAATGGACGGTACAAAGAGCTGCAAGACCGCGAGGTGGAGCTAATCTCATAAAACCGTT CTCAGTTCGGATTGTAGGCTGCAACTCGCCTACATGAAGCTGGAATCGCTAGTAATCGCGGATCAGCATGCCGC GGTGAATACGTTCCCGGGCCTTGTACACACCGCCCGTCACACCACGAGAGTTTGTAACACCCGAAGTCGGTGGG GTAACCTTTTTTG GAGCCAGCCGCTAAAG

Taxonomy classification: Bacillus cereus Frankland and Frankland 1887. Cellular organisms; Bacteria; Terrabacteria group; Firmicutes; Bacilli; Bacillales; Bacillaceae; Bacillus; Bacillus cereus group.

\subsection{Amylolysis Test}

The amylolysis test of the bacterium Bacillus cereus resulted in the formation of amylolysis halos around the 
bacterium colonies, after developing the plaque with iodine vapor, presenting IA = $3.3(10 / 3)$. Starch hydrolysis was given as a function of the release and action of amylolytic enzymes in the medium by the bacteria B. cereus, shown in Figure 3.

Figure 3 - Amylolysis halos around Bacillus cereus colonies.

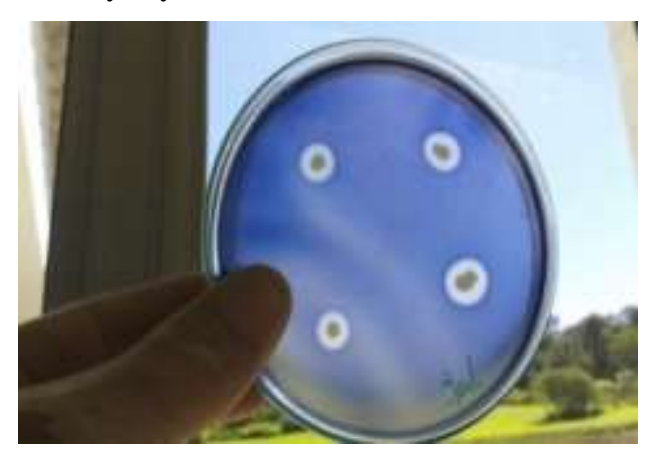

Source: Authors (2021).

\subsection{Starch Standard Curve}

The standard curve for starch (graphs 1 A and B) served as a basic parameter to analyze the degree of starch degradation in the analysis of enzymatic reactions (AE).

Graph 1 - Starch Standard Curve - Transmittance (A) and Absorbance (B) in $\lambda 620 \mathrm{~nm}$.
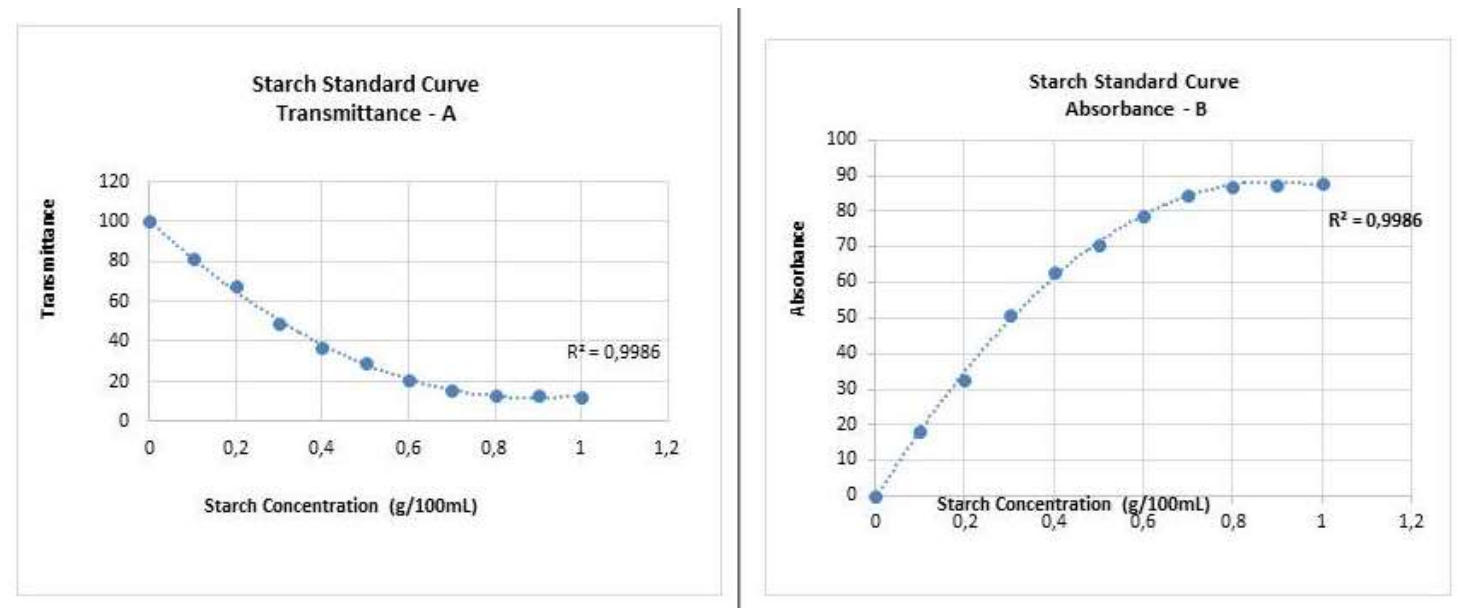

Source: Authors (2021).

The standard curve graph (Transmittance and Absorbance) serves as a linearity model with the concentration of starch present in the medium, allowing the identification of starch concentrations consumed in the enzymatic process throughout the process through mathematical calculations.

\subsection{Evaluation of the Enzymatic Activity of Amylases on the Starch Substrate}

The result of the Enzymatic Activity (AE) of the amylases synthesized by the microorganism Bacillus cereus, in the different treatments of the supernatant T1, T2, T3, T4 proved the effectiveness of the action of this microbial enzyme on the starch substrate, as shown in graphs 2, 3, 4 and 5 (Starch degradation over time), by transmittance and absorbance readings. 
Graph 2 - Enzymatic activity (AE: amylases in starch Substrate x Time).

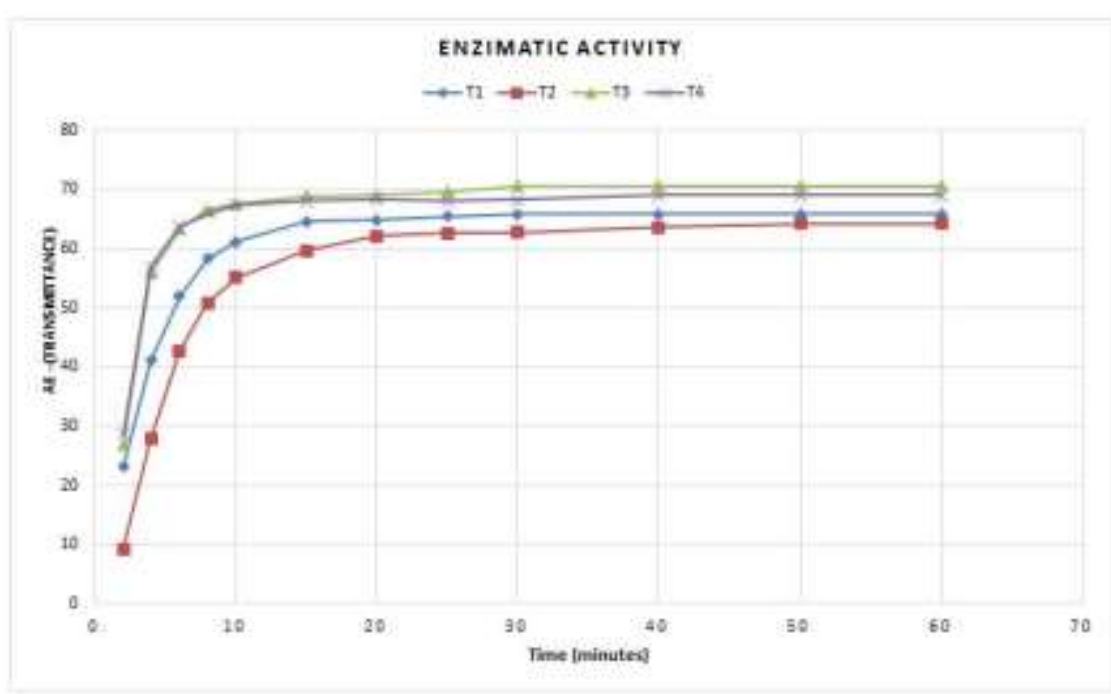

Source: Authors (2021).

In this Graph 2, it is possible to verify the degradation of the starch substrate as the transmittance increases over time. The curves presented in the treatments ( $\mathrm{T} 1$ to $\mathrm{T} 4$ ) represent the characteristic behavior of a first-order enzymatic reaction.

Graph 3 - Enzyme activity in starch degradation in grams x time (10 minutes): comparisons of T1 treatments (100 $\mu \mathrm{L}$ Enzyme centrifuged); and T2 (10 $\mu$ L Enzyme Centrifuged).

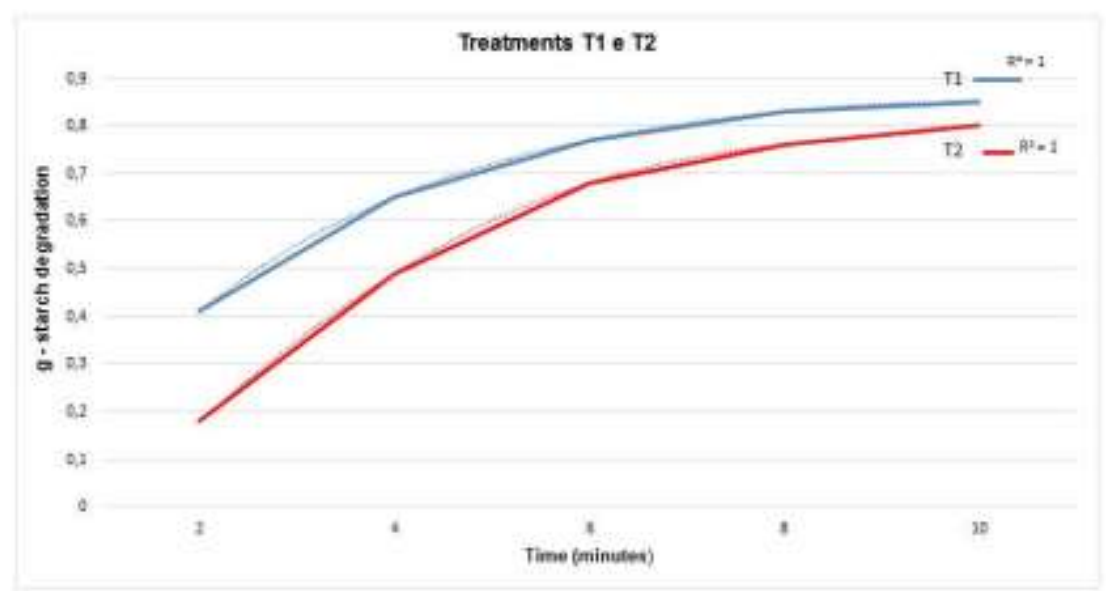

Source: Authors (2021).

From the curves in Graph 3, it can be seen that the T1 treatment has a higher enzyme concentration $(100 \mu \mathrm{L}$ of supernatant), which is why it presented a higher rate of starch degradation in the medium compared to T2. 
Graph 4 - Enzyme activity on starch degradation in grams x time (10 minutes), comparative of Treatments: T3 (10 $\mu \mathrm{L}$ membrane filtered supernatant of $0.22 \mu \mathrm{m}$ and $\mathrm{T} 4(100 \mu \mathrm{L}$ membrane filtered supernatant of $0.22 \mu \mathrm{m})$.

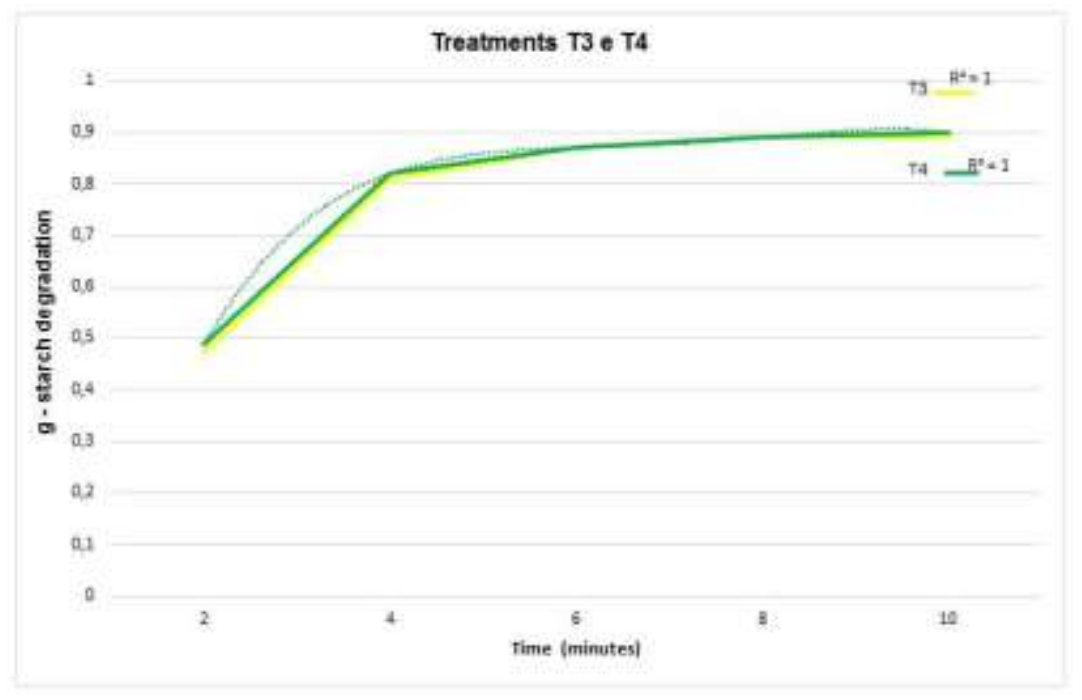

Source: Authors (2021)

The curves of the enzymatic reaction in the starch substrate in treatments 3 and 4 allow us to infer that the filtration of the supernatant in millipore membrane ensures the activity of the amylase enzyme in a more uniform way, since the difference between the concentrations of the treatments did not interfere in the kinetics of the reaction.

Graph 5 - Enzymatic activity on starch degradation in grams x time (10 minutes), comparison of Treatments T1, T2, T3 and T4.

Treatments T1, T2, T3 e T4

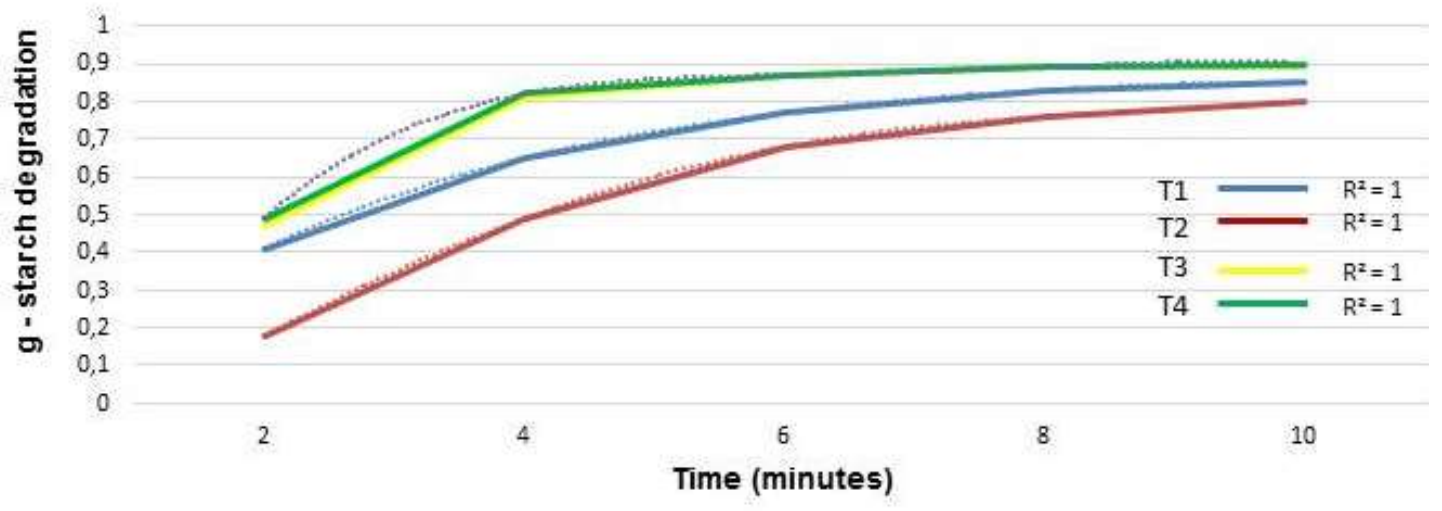

Source: Authors (2021).

In the graph above, it can be clearly observed that the treatments (T3, T4), which were subjected to the process of centrifugation and filtration in millipore membrane, had higher enzymatic activity than the treatments (T1, T2) which were subjected only to the centrifugation process of the supernatant.

\section{Discussion}

Microscopy analyzes of the microorganism indicated that it was of the Bacillus cereus species. The ratio of the diameters of amylolysis halos by the diameters of the colonies of this microorganism indicated a high production capacity of 
amylolytic enzymes, resulting in an Amylolysis Index (AI) of 3.3. By analyzing Graph 5, which shows the Enzyme Activity curves for the four treatments, it can be seen that the maximum Enzyme reaction speed, in general, occurred around the first 10 minutes for all treatments. However, Treatments 3 and 4 already showed a deflection of the curve in the first 4 minutes and the maximum speed after 6 minutes. Regarding the initial enzymatic activities, between the treatments "enzymatic solutions of the centrifuged supernatants and of the $0.22 \mu \mathrm{m}$ millipore membrane filtrates" of Bacillus cereus growth media, they proved that the filtration in $0.22 \mu \mathrm{m}$ millipore membrane (curves of the T3 and T4 treatments, present in the graph 4) it was more efficient to separate the enzymes from other residues present in the supernatant, which appeared to interfere slightly in the initial process of the reaction. Thus, between Treatments T1 and T2 (supernatants only submitted to centrifugation), there was a delay in the initial reaction time of treatment T2 in relation to T1, since treatment T2 contained a 10 times smaller aliquot of centrifuged supernatant (enzyme solution); which did not occur between treatments T3 and T4 (supernatants submitted to filtration in $0.22 \mu \mathrm{m}$ millipore membrane), even though the T4 treatment received an aliquot 10 times greater than the T3 treatment. Thus, the importance of enzyme purification treatments is highlighted, since the filtration process of Bacillus cereus culture supernatants on $0.22 \mu \mathrm{m}$ millipore membranes (T3 and T4) was more efficient in terms of amylase activity when compared to the centrifugation process. Among all the treatments evaluated, the treatment "T3" stood out, which showed greater efficiency in the starch hydrolysis process compared to the other treatments, since its enzymatic activity had higher initial reaction speed, with an aliquot of $10 \mu \mathrm{L}$ of solution enzymatic, and promoted the greatest degradation of the starch substrate around $92 \%$ within 30 minutes of the hydrolysis process.

\section{Conclusions}

The tests developed were very fruitful, it can be proven that the microorganism "Bacillus cereus" produced amylase enzymes with high potential for amylolytic action, which may be suitable for industrial processes in the various areas of interest to humanity, requiring the optimization of growth parameters microbial and amylase production, such as: culture media, $\mathrm{pH}$, temperature, rpm, time, growth factors, amylase inducers, as well as the use of down-stream technologies to purify biosynthesized enzymes to scale-up processes. In this sense, it is concluded that biotechnology is a science of theoretical and practical excellence, viable for the prospecting of microorganisms with faculties in generating bioproducts, both for scientific uses and for industrial purposes; it is also inferred that the bacterium Bacillus cereus is a microorganism with biotechnological potential for the production of other substances of high importance in the field of animal and human health, such as antimicrobials and probiotics, in addition to the amylase enzyme, proven in this work.

In future works, we will aim at standardizing and optimizing the bioprocess, such as: temperature; $\mathrm{pH}$; Rpm; use of growth media with the addition of ions and inducers to improve the microorganism's adaptation and accelerate the growth phase, as well as to direct gene expression to the synthesis of amylases; evaluation of enzymatic activity by varying the substrate concentration; purification of the supernatant with different filter elements.

\section{References}

Abreu, J. A. S., Rovida, A. F. D. S., \& Pamphile, J. A. (2015). Fungos de interesse: aplicações biotecnológicas. Revista UNINGÁ Review, 21(1).

Abriouel, H., Franz, C. M., Omar, N. B., \& Gálvez, A. (2011). Diversity and applications of Bacillus bacteriocins. FEMS microbiology reviews, 35(1), 201232 .

Ashwini, K., Gaurav, K., Karthik, L., \& Bhaskara Rao, K. V. (2011). Optimization, production and partial purification of extracellular $\alpha$-amylase from Bacillus sp. marini. Arch Appl Sci Res, 3(1), 33-42.

Astolfi Filho, S., Galembeck, E. V., Faria, J. B., \& Frascino, A. C. S. (1986). Stable Yeast Transformants that Secrete Functional $\alpha-$ Amylase Encoded by Cloned Mouse Pancreatic cDNA. Biotechnology, 4(4), 311-315.

Beattie, A. J., Hay, M., Magnusson, B., de Nys, R., Smeathers, J., \& Vincent, J. F. (2011). Ecology and bioprospecting. Austral ecology, $36(3)$, $341-356$. 
Begley, M., Hill, C., \& Gahan, C. G. (2006). Bile salt hydrolase activity in probiotics. Applied and environmental microbiology, 72(3), 1729-1738.

Brazil. Ministério da Saúde. Organização Pan-Americana da Saúde. Ministério da Ciência e Tecnologia. Caracterização do Estado da Arte em Biotecnologia Marinha no Brasil. Brasília: Ministério da Saúde, 2010. http://bvsms.saude.gov.br/bvs/publicacoes/caracterizacao_estado_arte_biotecnologia_marinha.pdf>

Brazil. Ministério da Indústria, Comércio Exterior e Serviços. 2018. http://www.mdic.gov.br/ comercioexterior/estatisticasdecomercio exterior/ comex-vis/ frame-ppi?ppi=3161

Brasília. Ministério da Saúde. Técnica de Coloração de Gram. Ministério da Saúde, Programa Nacional de Doenças Sexualmente Transmissíveis e AIDS, 2001 https://bvsms.saude.gov.br/bvs/publicacoes/115_03gram.pdf

Caraway, W. T. (1959). A stable starch substrate for the determination of amylase in serum and other body fluids. American Journal of Clinical Pathology, 32, 97-99.

Carrín, M. E., Ceci, L. N., \& Lozano, J. E. (2004). Characterization of starch in apple juice and its degradation by amylases. Food Chemistry, 87(2), 173-178.

Chi, Z., Chi, Z., Liu, G., Wang, F., Ju, L., \& Zhang, T. (2009). Saccharomycopsis fibuligera and its applications in biotechnology. Biotechnology advances, 27(4), 423-431.

Couto, S. R., \& Sanromán, M. A. (2006). Application of solid-state fermentation to food industry- a review. Journal of Food Engineering, 76(3), 291-302.

Dalvi, P., \& Anthappan, P. (2007). Amylase and pectinase from single source for simultaneous desizing and scouring.

Demirkan, E. S., Mikami, B., Adachi, M., Higasa, T., \& Utsumi, S. (2005). $\alpha$-Amylase from B. amyloliquefaciens: purification, characterization, raw starch degradation and expression in E. coli. Process Biochemistry, 40(8), 2629-2636.

FAO/WHO. (2001). Health and nutritional properties of probiotics in food including powder milk live lactic acid bacteria. Joint Food and Agricultural Organization of the United Nations and World Health Organization Expert Consultation Report, Cordoba, Argentina. http://www.who.int/foodsafety/publications/fs_management/probiotics/en/index.html.

Gopinath, S. C., Anbu, P., Arshad, M. M., Lakshmipriya, T., Voon, C. H., Hashim, U., \& Chinni, S. V. (2017). Biotechnological processes in microbial amylase production. BioMed research international, 2017.

Gupta, R., Gigras, P., Mohapatra, H., Goswami, V. K., \& Chauhan, B. (2003). Microbial $\alpha$-amylases: a biotechnological perspective. Process biochemistry, 38(11), 1599-1616.

Hankin, L., \& Anagnostakis, S. L. (1975). The use of solid media for detection of enzyme production by fungi. Mycologia, 67(3), 597-607.

Hmidet, N., Ali, N. E. H., Haddar, A., Kanoun, S., Alya, S. K., \& Nasri, M. (2009). Alkaline proteases and thermostable $\alpha$-amylase co-produced by Bacillus licheniformis NH1: Characterization and potential application as detergent additive. Biochemical Engineering Journal, 47(1-3), 71-79.

Hong, H. A., Duc, L. H., \& Cutting, S. M. (2005). The use of bacterial spore formers as probiotics. FEMS microbiology reviews, 29(4), 813-835.

Ibrahim, S. A., \& O'Sullivan, D. J. (2000). Use of chemical mutagenesis for the isolation of food grade $\beta$-galactosidase overproducing mutants of Bifidobacteria, Lactobacilli and Streptococcus thermophilus. Journal of dairy science, 83(5), 923-930.

Ishibashi, N., \& Yamazaki, S. (2001). Probiotics and safety. The American journal of clinical nutrition, 73(2), 465s-470s.

Kumar, S., \& Khare, S. K. (2015). Chloride activated halophilic $\alpha$-amylase from Marinobacter sp. EMB8: Production optimization and nanoimmobilization for efficient starch hydrolysis. Enzyme research, 2015.

Kumar, S., \& Stecher, G. Tamura. K. (2016). MEGA7: Molecular Evolutionary Genetics Analysis version 7.0 for bigger datasets. Mol. Biol. Evol, 33(7), 1870-1874.

Lin, L. L., Chyau, C. C., \& Hsu, W. H. (1998). Production and properties of a raw-starch-degrading amylase from the thermophilic and alkaliphilic Bacillus sp. TS-23. Biotechnology and applied biochemistry, 28(1), 61-68.

Logan, N. A., \& De Vos, P. (2009). Genus Bacillus Cohn 1872. In: De Vos, P., et al., Eds., Bergey's Manual of Systematic Bacteriology, 3, $21-128$.

Malkov, S. V., Markelov, V. V., Polozov, G. Y., Sobchuk, L. I., Zakharova, N. G., Barabanschikov, B. I., \& Trushin, M. V. (2005). Antitumor features of Bacillus oligonitrophilus KU-1 strain. Journal of Microbiology, Immunology and Infection, 38(2), 96-104.

Mattila-Sandholm, T., Myllärinen, P., Crittenden, R., Mogensen, G., Fondén, R., \& Saarela, M. (2002). Technological challenges for future probiotic foods. International Dairy Journal, 12(2-3), 173-182.

Milner, J. A., Martin, D. J., \& Smith, A. (1996). Oxygen transfer conditions in the production of alpha-amylase by Bacillus amyloliquefaciens. Enzyme and microbial technology, 18(7), 507-512.

Morita, T., \& Assumpção, R. (2007). Manual de soluções, reagentes e solventes: padronização, preparação, purificação, indicadores de segurança e descarte de produtos químicos. Editora Blucher.

Morcel, C., \& Biedermann, K. (1994). Coupling of fermentation and microfiltration for $\alpha$-amylase production from Bacillus amyloliquefaciens. FEMS microbiology reviews, 14(1), 57-61.

Nedelcheva, P., Denkova, Z., Denev, P., Slavchev, A., \& Krastanov, A. (2010). Probiotic strain Lactobacillus plantarum NBIMCC 2415 with antioxidant activity as a starter culture in the production of dried fermented meat products. Biotechnology \& Biotechnological Equipment, 24(1), 1624-1630. 
Nielsen, J. E., \& Borchert, T. V. (2000). Protein engineering of bacterial $\alpha$-amylases. Biochimica et Biophysica Acta (BBA)-Protein Structure and Molecular Enzymology, 1543(2), 253-274.

Nithya, V., \& Halami, P. M. (2013). Evaluation of the probiotic characteristics of Bacillus species isolated from different food sources. Annals of Microbiology, 63(1), 129-137.

Oliveira, C., Muller, F., \& SEgato, M. (2004). Departamento de Engenharia Química e de Alimentos. Aplicações de enzimas em produtos de limpeza. Trabalhos de graduação do grupo de processos biotecnológicos da UFSC. Florianópolis: Universidade Federal de Santa Catarina.

Pandey, A., Soccol, C. R., Nigam, P., \& Soccol, V. T. (2000). Biotechnological potential of agro-industrial residues. I: sugarcane bagasse. Bioresource technology, 74(1), 69-80.

Pandey, A. (2003). Solid-state fermentation. Biochemical engineering journal, 13(2-3), 81-84.

Pandey, A., Webb, C., Soccol, C. R., \& Larroche, C. (Eds.). (2006). Enzyme technology. Springer Science \& Business Media.

Parvez, S., Malik, K. A., Ah Kang, S., \& Kim, H. Y. (2006). Probiotics and their fermented food products are beneficial for health. Journal of applied microbiology, 100(6), 1171-1185.

Peixoto, S. C., Jorge, J. A., Terenzi, H. F., \& Maria de Lourdes, T. M. (2003). Rhizopus microsporus var. rhizopodiformis: a thermotolerant fungus with potential for production of thermostable amylases. International Microbiology, 6(4), 269-273.

Politzer, K., \& Bon, E. D. S. (2006). Enzimas industriais e especiais. Centro de Gestão e Estudos Estratégicos, Ciência, Tecnologia e Inovação, IQ/UFRJ, Rio de janeiro.

Priest, F. G. (1977). Extracellular enzyme synthesis in the genus Bacillus. Bacteriological reviews, 41(3), 711-753.

Rajkowski, K. T., \& Bennett, R. W. (2003). Bacillus cereus. In International handbook of foodborne pathogens (pp. 47-60). CRC Press.

Rhodes, J. C. (2006). Aspergillus fumigatus: growth and virulence. Medical mycology, 44(Supplement_1), S77-S81.

Sajedi, R. H., Naderi-Manesh, H., Khajeh, K., Ahmadvand, R., Ranjbar, B., Asoodeh, A., \& Moradian, F. (2005). A Ca-independent $\alpha$-amylase that is active and stable at low pH from the Bacillus sp. KR-8104. Enzyme and Microbial Technology, 36(5-6), 666-671.

Sarikaya, E., Higasa, T., Adachi, M., \& Mikami, B. (2000). Comparison of degradation abilities of $\alpha$-and $\beta$-amylases on raw starch granules. Process Biochemistry, 35(7), 711-715.

Yoon, S., Ryu, S. I., Lee, S. B., \& Moon, T. W. (2008). Purification and characterization of branching specificity of a novel extracellular amylolytic enzyme from marine hyperthermophilic Rhodothermus marinus. Journal of microbiology and biotechnology, 18(3), 457-464.

Shimada, H., Honjo, M., Mita, I., Nakayama, A., Akaoka, A., Manabe, K., \& Furutani, Y. (1985). The nucleotide sequence and some properties of the neutral protease gene of Bacillus amyloliquefaciens. Journal of biotechnology, 2(2), 75-85.

Sidhu, G. S., Sharma, P., Chakrabarti, T., \& Gupta, J. K. (1997). Strain improvement for the production of a thermostable $\alpha$-amylase. Enzyme and Microbial Technology, 21(7), 525-530.

Singh, J. S., Pandey, V. C., \& Singh, D. P. (2011). Efficient soil microorganisms: a new dimension for sustainable agriculture and environmental development. Agriculture, ecosystems \& environment, 140(3-4), 339-353.

Swetha, S., Dhanya, G., Kesavan, M. N., Carlos, R. S., \& Ashok, P. (2006). $\alpha$-Amylases from Microbial Sources-An Overview on Recent Developments. Food Technol Biotechnol, 44(2), 173-184.

Soccol, C. R., Rojan, P. J., Patel, A. K., Woiciechowski, A. L., Vandenberghe, L. P., \& Pandey, A. (2006). Glucoamylase. In Enzyme technology (pp. 221237). Springer, New York, NY.

Souza, P. M. D., \& Magalhães, P. D. O. (2010). Application of microbial $\alpha$-amylase in industry-A review. Brazilian journal of microbiology, 41 , 850-861.

Sundarram, A., \& Murthy, T. P. K. (2014). a-amylase production and applications: a review. Journal of Applied \& Environmental Microbiology, 2(4), 166175 .

Surmely, R., Alvarez, H., Cereda, M. P., \& Vilpoux, O. F. (2003). Hidrólise do amido. Culturas de tuberosas amiláceas latino americanas, 3 , $377-395$.

Van Der Maarel, M. J., Van der Veen, B., Uitdehaag, J. C., Leemhuis, H., \& Dijkhuizen, L. (2002). Properties and applications of starch-converting enzymes of the $\alpha$-amylase family. Journal of biotechnology, 94(2), 137-155.

Vasiljevic, T., \& Shah, N. P. (2008). Probiotics - from Metchnikoff to bioactives. International Dairy Journal, 18(7), 714-728.

Vehmaanperä, J., Steinborn, G., \& Hofemeister, J. (1991). Genetic manipulation of Bacillus amyloliquefaciens. Journal of biotechnology, 19(2-3), 221-240.

Weisburg, W. G., Barns, S. M., Pelletier, D. A., \& Lane, D. J. (1991). 16S ribosomal DNA amplification for phylogenetic study. Journal of bacteriology, 173(2), 697-703.

Welker, N. E., \& Campbell, L. L. (1965). Induction and properties of a temperate bacteriophage from Bacillus stearothermophilus. Journal of bacteriology, 89(1), 175-184.

Wohlgemuth, R. (2010). Biocatalysis - key to sustainable industrial chemistry. Current opinion in biotechnology, 21(6), 713-724. 